OPEN ACCESS

Edited by:

Mariusz Cycoń,

Medical University of Silesia, Poland

Reviewed by:

Eric D. van Hullebusch,

UMR7154 Institut de Physique du

Globe de Paris (IPGP), France

Kazuhiro Mori,

University of Yamanashi, Japan

${ }^{*}$ Correspondence:

Xingjian Xu

xxjclean@126.com

Hongwen Yu

Yuhw@neigae.ac.cn

Specialty section:

This article was submitted to Microbiotechnology, Ecotoxicology and Bioremediation,

a section of the journal

Frontiers in Microbiology

Received: 15 September 2018 Accepted: 12 November 2018 Published: 03 December 2018

Citation:

Xu X, Liu W, Tian S, Wang W, Qi Q, Jiang P, Gao X, Li F, Li H and Yu H (2018) Petroleum

Hydrocarbon-Degrading Bacteria for the Remediation of Oil Pollution

Under Aerobic Conditions:

A Perspective Analysis.

Front. Microbiol. 9:2885.

doi: 10.3389/fmicb.2018.02885

\section{Petroleum Hydrocarbon-Degrading Bacteria for the Remediation of Oil Pollution Under Aerobic Conditions: A Perspective Analysis}

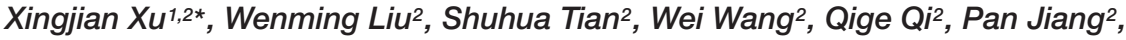 \\ Xinmei Gao', Fengjiao $\mathrm{Li}^{2}$, Haiyan $\mathrm{Li}^{1,3}$ and Hongwen $\mathrm{Yu}^{1,3 *}$ \\ ${ }^{1}$ Northeast Institute of Geography and Agroecology, Chinese Academy of Sciences, Changchun, China, ${ }^{2}$ Hinggan League \\ Academy of Agriculture and Animal Husbandry, Ulanhot, China, ${ }^{3}$ School of Life Science and Technology, Changchun \\ University of Science and Technology, Changchun, China
}

With the sharp increase in population and modernization of society, environmental pollution resulting from petroleum hydrocarbons has increased, resulting in an urgent need for remediation. Petroleum hydrocarbon-degrading bacteria are ubiquitous in nature and can utilize these compounds as sources of carbon and energy. Bacteria displaying such capabilities are often exploited for the bioremediation of petroleum oilcontaminated environments. Recently, microbial remediation technology has developed rapidly and achieved major gains. However, this technology is not omnipotent. It is affected by many environmental factors that hinder its practical application, limiting the large-scale application of the technology. This paper provides an overview of the recent literature referring to the usage of bacteria as biodegraders, discusses barriers regarding the implementation of this microbial technology, and provides suggestions for further developments.

Keywords: petroleum hydrocarbon-degrading bacteria, petroleum oil, bioremediation, bacterial consortia, environmental factors, enzymes

\section{INTRODUCTION}

Petroleum oil is an important strategic resource for which all countries compete fiercely (Sun, 2009). Indeed, anthropogenic activity is reliant on oil to meet its energy demands, which causes the petrochemical industry to flourish. However, petroleum use results in environmental deterioration (Xue et al., 2015). During petroleum production, storage and transportation, refining and processing, as well as spills and discharges of petroleum hydrocarbons often occur as a result of blowout accidents during oilfield development, leakage from oil pipelines and storage tanks, oil tanker and tanker leakage accidents, oil well waxing, and during overhauls of refineries and petrochemical production equipment (Chaerun et al., 2004; Chen et al., 2015; Wang C. et al., 2018). Large spills should be recycled or eliminated to as great a degree as possible, but in some cases it is difficult to recover the spilled materials, resulting in its remaining in the affected area, and posing persistent risks to the environment.

Accordingly, there is a constant threat of contamination wherever oil is exploited when coupled with an insufficient ability to deal with oil-contaminated environments, especially in extreme or unique environments such as polar regions, deep sea areas, deserts, and wetlands. Although oil 
pollution is difficult to treat, petroleum hydrocarbon-degrading bacteria have evolved as a result of existing in close proximity to naturally occurring petroleum hydrocarbons in the environment. Such organisms are candidates for the treatment of oil pollutants (Margesin et al., 2003; Ron and Rosenberg, 2014; Lea-Smith et al., 2015). Therefore, bacteria have been screened and utilized to degrade waste products produced by the food, agricultural, chemical and pharmaceutical industries. In recent years, the use of bacteria to deal with environmental pollutants has become a promising technology because of its low cost and eco-friendly nature (Guerra et al., 2018). The continuous development and improvement of microbial remediation technology has also provided a new method for the remediation of petroleum hydrocarbon pollution, which has attracted much attention (Dombrowski et al., 2016; Dvořák et al., 2017). The purpose of this review article is to provide some suggestions for the future development of bacterial remediation of petroleum hydrocarbons on the basis of previously published studies related to new advances in the area of bacterial remediation of petroleum hydrocarbons.

\section{PETROLEUM HYDROCARBON-DEGRADING BACTERIA}

Most petroleum hydrocarbons encountered in the environment are ultimately degraded or metabolized by indigenous bacteria because of their energetic and carbon needs for growth and reproduction, as well as the requirement to relieve physiological stress caused by the presence of petroleum hydrocarbons in the microbial bulk environment (Hazen et al., 2010; Kleindienst et al., 2015a). The development of microbial biotechnology and high-throughput sequencing technology, such as microfluidic techniques (Jiang et al., 2016; Guerra et al., 2018), is beneficial for screening and identifying functional microorganisms from petroleum hydrocarboncontaminated environments. Indeed, many studies have revealed that there is a large number of hydrocarbon-degrading bacteria in oil-rich environments, such as oil spill areas and oil reservoirs (Hazen et al., 2010; Yang et al., 2015), and that their abundance and quantity are closely related to the types of petroleum hydrocarbons and the surrounding environmental factors (Fuentes et al., 2015; Varjani and Gnansounou, 2017).

Many normal and extreme bacterial species have been isolated and utilized as biodegraders for dealing with petroleum hydrocarbons. The degradation pathways of a variety of petroleum hydrocarbons (e.g., aliphatics and polyaromatics) have been shown to employ oxidizing reactions; however, these pathways differ greatly because of the specific oxygenases found in different bacterial species. For instance, some bacteria can metabolize specific alkanes, while others break down aromatic or resin fractions of hydrocarbons. This phenomenon is related to the chemical structure of petroleum hydrocarbon components. Petroleum hydrocarbon-degrading bacteria and the type of petroleum components they degrade are listed in Table $\mathbf{1}$.
Recent studies have identified bacteria from more than 79 genera that are capable of degrading petroleum hydrocarbons (Tremblay et al., 2017); several of these bacteria such as Achromobacter, Acinetobacter, Alkanindiges, Alteromonas, Arthrobacter, Burkholderia, Dietzia, Enterobacter, Kocuria, Marinobacter, Mycobacterium, Pandoraea, Pseudomonas, Staphylococcus, Streptobacillus, Streptococcus, and Rhodococcus have been found to play vital roles in petroleum hydrocarbon degradation (Margesin et al., 2003; Chaerun et al., 2004; Jin et al., 2012; Nie et al., 2014; Varjani and Upasani, 2016; Sarkar et al., 2017; Varjani, 2017; Xu et al., 2017). Interestingly, "conditionally rare taxa" in soil, such as Alkanindiges sp., have been reported to exhibit rare-to-dominant bacterial shifts that are strongly affected by environmental constrains such as diesel pollution (Fuentes et al., 2015). Similarly, some obligate hydrocarbonoclastic bacteria (OHCB), including Alcanivorax, Marinobacter, Thallassolituus, Cycloclasticus, Oleispira and a few others (the OHCB), showed a low abundance or undetectable status before pollution, but were found to be dominant after petroleum oil contamination (Yakimov et al., 2007). These phenomena suggest that these microorganisms are crucial to the degradation of petroleum hydrocarbons, and that they significantly influence the transformation and fate of petroleum hydrocarbons in the environment. Although some bacteria have been reported to have a broad spectrum of petroleum hydrocarbon degradation ability, Dietzia sp. DQ12-45-1b utilizes $n$-alkanes (C6-C40) and other compounds as the sole carbon sources (Wang et al., 2011) and Achromobacter xylosoxidans DN002 works well on a variety of monoaromatic and polyaromatic hydrocarbons (Ma et al., 2015), almost no bacteria can degrade the entire petroleum hydrocarbon fraction. Indeed, most bacteria can only effectively degrade or utilize certain petroleum hydrocarbon components, while others are completely unavailable (Chaerun et al., 2004; Varjani, 2017). This can be attributed to the fact that different indigenous bacteria have different catalytic enzymes; thus, their roles in oilcontaminated sites also vary widely. This also implies that the remediation of petroleum hydrocarbon contamination requires the joint action of multiple functional bacteria to achieve the best environmental purification effect (Dombrowski et al., 2016). Based on this view, Varjani et al. (2015) constructed a halotolerant Hydrocarbon Utilizing Bacterial Consortium (HUBC) consisting of the bacterial isolates Ochrobactrum sp., Stenotrophomonas maltophilia and Pseudomonas aeruginosa that was found to be good at degrading crude oil $(3 \% \mathrm{v} / \mathrm{v})$, with a degradation percentage as high as $83.49 \%$. Tao et al. (2017) utilized a defined co-culture of an indigenous bacterial consortium and exogenous Bacillus subtilis to effectively accelerate the degradation of crude oil. Wang C. et al. (2018) found that an aboriginal bacterial consortium based on the Penglai 19-3 oil spill accident (China) had higher oil degradation efficiency compared to individual bacteria and demonstrated that this indigenous consortium had the potential for bioremediating crude oil dispersed in the marine ecosystem. A field study showed that bioaugmentation with an artificial consortium containing Aeromonas hydrophila, 
Alcaligenes xylosoxidans, Gordonia sp., Pseudomonas fluorescens, Pseudomonas putida, Rhodococcus equi, S. maltophilia, and Xanthomonas sp. contributed to high biodegradation efficiency (89\%) in a 365-day treatment of diesel oil-contaminated soil (Szulc et al., 2014). Taken together, these studies indicate that improving the biodegradation potential via the application of bacterial consortia possessing multiple catabolic genes is a reasonable and feasible strategy for accelerating the removal efficiency of petroleum hydrocarbons from contaminated environments.

\section{TOXIC IMPACT OF PETROLEUM HYDROCARBONS}

The harm that oil pollution causes to the ecological environment is well known (Sikkema et al., 1995). For example, the Deep Water Horizon oil spill accident in the Gulf of Mexico produced a profound impact on the economy and environmental safety, which is still the focus of people's attention (Xue et al., 2015). Although people are becoming increasingly concerned about the toxic effects of oil pollution on humans and animals in

TABLE 1 | Petroleum hydrocarbon-degrading bacteria and their preferred degradation substrates.

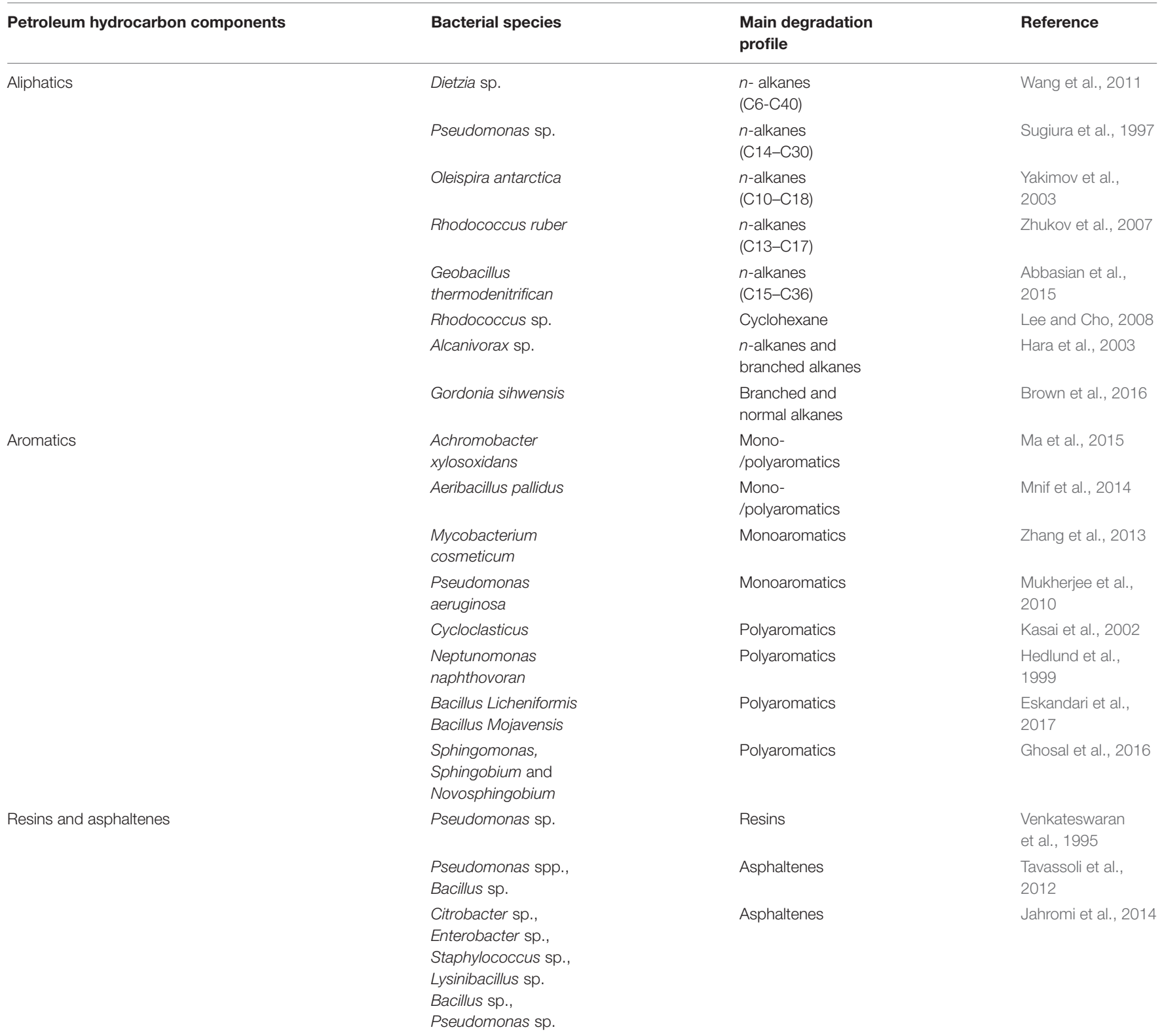

Some petroleum hydrocarbon-degrading strains have been studied as model organisms to further reveal the mode of action of bacteria in degrading petroleum hydrocarbons, degradation pathways, molecular mechanisms, etc. Moreover, it has been known for some time that the use of bacteria to degrade petroleum hydrocarbons is not always successful and is affected by many factors, including the toxic effects of petroleum hydrocarbons on bacteria, the bioavailability of petroleum hydrocarbons, environmental constraints, metabolic restriction and long remediation periods (Head et al., 2006; Figure 1). 
affected areas, (Díez et al., 2007; Mason et al., 2012), the strong toxic impacts of petroleum hydrocarbons on affected microbial communities are often overlooked (Rivers et al., 2013; Overholt et al., 2015). Labud et al. (2007) reported that petroleum hydrocarbons inhibited microbial biomass, and that the greatest negative effects were observed in the gasoline-polluted sandy soil. In diesel exposure experiments, researchers found that the primary effects of diesel fuel toxicity were reductions in species richness, evenness and phylogenetic diversity, with the resulting community being heavily dominated by a few species, principally Pseudomonas. Moreover, they found that the decline in richness and phylogenetic diversity was linked to the disruption of the nitrogen cycle, with species and functional genes involved in nitrification being significantly reduced (van Dorst et al., 2014). Cerniglia et al. (1983) investigated the toxicity of naphthalene, 1-methylnaphthalene, and 2-methylnaphthalene as well as their oxygenated derivatives to bacterial cells of Agmenellum quadruplicatum, and found that these compounds produced no significant inhibitory effects on bacterial growth. However, the phenolic and quinonic naphthalene derivatives inhibited bacterial growth. This could be explained by phenols and quinones with higher solubility, enhancing the mass transfer of molecules to bacterial cells, resulting in higher toxic effects than the former compounds. Several studies have also reported that certain metabolic intermediates with relatively high solubility produced from the degradation of petroleum hydrocarbons by bacteria may have higher cytotoxicity than the parent molecules and therefore damage the bacteria (Hou et al., 2018). However, indigenous bacteria form very large aggregates, and each species has its own function. Accordingly, while some bacteria that are sensitive to petroleum hydrocarbons are greatly inhibited upon exposure to petroleum hydrocarbons, others that can efficiently degrade petroleum hydrocarbons, as well as bacteria that can take advantage of cytotoxic intermediate metabolites, will flourish. However, clean-up of petroleum oil pollutants by relying on the strength of these indigenous microorganisms alone will take a long time; therefore, it is necessary to develop intervention measures to speed the process up.

\section{RESTRICTION OF PHYSICAL CONTACT BETWEEN BACTERIA AND PETROLEUM HYDROCARBONS}

Due to the hydrophobicities and low water solubilities of most petroleum hydrocarbons, the biodegradation rate is generally limited in the environment. This is because the first step in the degradation process of petroleum oil often requires the participation of bacterial membrane-bound oxygenases, which require direct and effective contact between bacterial cells and petroleum hydrocarbon substrates. The primary factors restricting the biodegradation efficiency of petroleum hydrocarbons are as follows: (1) limited bioavailability of petroleum hydrocarbons to bacteria, and (2) the fact that bacterial cell contact with hydrocarbon substrates is a requirement before introduction of molecular oxygen into molecules by the functional oxygenases (Vasileva-Tonkova et al., 2008; Hua and Wang, 2014). However, bacteria have evolved countermeasures against petroleum contaminants, such as improving the adhesion ability of cells by altering their surface components and secreting bioemulsifier to enhance their access to target hydrocarbon substrates. Bacteria with such functions are often screened for use as environmental remediation agents, accelerating the removal of petroleum hydrocarbon pollutants from the environment (Kaczorek et al., 2012; Krasowska and Sigler, 2014).

Bacterial surface properties are essential to the effective biodegradation of hydrophobic hydrocarbon substrates (Figure 2) and their adhesion mechanisms are of great importance (Zhang et al., 2015). Ron and Rosenberg (2014) found that adherence of hydrophobic pollutants to bacterial cells is mainly related to hydrophobic fimbriae, fibrils, outer-membrane proteins and lipids, as well as certain small molecules present in cell surfaces such as gramicidin $S$ and prodigiosin. Fimbriae present on bacterial surfaces were confirmed to be necessary for the growth of Acinetobacter sp. RAG-1, with $\mathrm{C}_{16}$ alkane as the carbon source and beneficial to bacterial adherence, assimilation hydrophobic substrates and their metabolic activity (Rosenberg and Rosenberg, 1985). Nevertheless, bacterial capsules and several anionic exopolysaccharides produce inhibitory effects on hydrocarbon substrate adhesion. For example, Bacillus licheniformis decreases cell surface hydrophobicity in response to exposure to organic solvents and has little affinity for toxic organic compounds (Torres et al., 2011). Although bacterial adherence can enhance the biodegradation of hydrophobic hydrocarbons, it is not necessary to attach bacterial cells to targeted substrates (Abbasnezhad et al., 2011). This is because, in some instances, bacteria with high surface hydrophobicity are easily aggregated and form biofilms, thereby producing potential risks such as diseases (Doyle, 2000). Indeed, not only hydrophobic bacteria can biodegrade hydrophobic pollutants; several solvent-resistant hydrophilic bacteria are also capable of metabolizing such pollutants (Heipieper et al., 2007), which may be because of the modification of lipopolysaccharides or porines of the outer membrane of the bacterial surface (Krasowska and Sigler, 2014). Megharaj et al. (2011) also reported that the solvent-resistant bacteria were first to colonize and dominate for the removal of pollutants. Therefore, the use of hydrophilic microorganisms to treat hydrocarbon pollutants seems to be more advantageous than hydrophobic microorganisms (Obuekwe et al., 2009).

To enhance the bioavailability of petroleum hydrocarbons, one promising approach is the application of surfactants (Kleindienst et al., 2015a), which may enhance dissolution or desorption rates leading to the solubilization or emulsification of petroleum hydrocarbon pollutants (Varjani and Upasani, 2017). Chen et al. (2007) found that the adherence of Bacillus sp. DQ02 to hydrocarbon increased $44 \%$ in the presence of rhamnolipids and that the degradation of $n$-hexadecane increased $11.6 \%$ compared to treatment in the absence of rhamnolipids. However, some surfactants, such as Corexit 9500, were reported to exhibit adverse impacts on oil-degrading bacteria (Kleindienst et al., 2015b) because of toxicity of the surfactant toward bacteria or as a result of competition of the surfactant with hydrocarbon 
substrates (Laha and Luthy, 1991; Liu et al., 2016). In view of this, the selection of appropriate surfactants is of great importance for pollution remediation and the prevention of secondary pollution. Bioemulsifier-producing bacteria, which have attracted much attention, generally have the following two physiological aspects: (1) the ability to enhance the complexation and solubilization of non-polar substrates, thereby promoting the bioavailability of substrates, and (2) the ability to improve affinity between cell surfaces and oil-water interfaces through metabolism, promoting deformation of the oil-water interface film (Hou et al., 2018). Ayed et al. (2015) reported that the biosurfactant produced by Bacillus amyloliquefaciens An6 was an alternative to chemically synthesized surfactants since it showed high solubilization efficiency toward diesel oil (71.54\% at $1 \mathrm{~g} / \mathrm{L})$ that was better than SDS and Tween 80 and could enhance the diesel oil degradation efficiency of the An6 strain. However, not all the biosurfactants produced by bioemulsifier-producing bacteria can effectively enhance the degradation rate of pollutants (Inakollu et al., 2004). Indeed, whether various biosurfactants stimulate or inhibit the bioremediation of pollutants is dependent on the physico-chemical properties of the surfactants, types of pollutants and physiological characteristics of the functional microorganisms (Hua and Wang, 2014). Therefore, it is necessary to establish a database of petroleum hydrocarbon pollutants and bioemulsifier-producing bacteria which is conducive to the targeted selection of suitable bacteria to treat with petroleum hydrocarbons.

\section{ENVIRONMENTAL CONSTRAINTS}

Many environmental factors such as temperature, nutrients, electron acceptors and substrates play vital roles in bioremediation and influence biodegradation reactions (Varjani and Upasani, 2017). This is why most researchers have found that many petroleum hydrocarbon-degrading bacteria can achieve excellent results during degradation of petroleum hydrocarbons under laboratory conditions yet exhibit dissatisfactory results in field-scale tests (Head et al., 2006). The bacterial strains Acinetobacter sp. JLS1 and P. aeruginosa JLC1, isolated from Momoge wetlands in Jilin Province, China, showed different sensitivity to temperature during the biodegradation process of $\mathrm{C}_{16}$ alkane, suggesting that temperature strongly affected biodegradation efficiency ( $\mathrm{Li}$ et al., 2017; Xu et al., 2017). In a laboratory study, the petroleum hydrocarbons phenanthrene and dibenzothiophenes were well degraded, but similar degradation effects did not occur in a field experiment, which could be attributed to the temperature range during the study (Röling et al., 2002, 2004). Indeed, temperature can affect bacterial growth and metabolism, the soil matrix and the mode of occurrence of pollutants, thereby indirectly affecting biodegradation efficiency (Abed et al., 2015). It is well known that the growth of bacteria requires sufficient carbon, hydrogen, oxygen, nitrogen, sulfur, phosphorus, and various trace elements. However, the main components of petroleum hydrocarbons are only carbon and hydrogen, therefore the environment must have enough other nutrient elements to ensure growth of bacterial degraders. It is estimated that approximately $150 \mathrm{~g}$ of nitrogen and $30 \mathrm{~g}$ of phosphorous are consumed to convert $1 \mathrm{~kg}$ of hydrocarbons in bacterial cells (Ron and Rosenberg, 2014). Extensive laboratory and field studies have been devoted to solving this problem. The addition of fertilizers containing bioavailable nitrogen and phosphorus has been successfully applied to stimulate petroleum oil biodegradation on a number of different shorelines and sandy beaches (Röling et al., 2002; Hazen et al., 2016). Soluble and non-soluble nutrients suffer from problems in the actual remediation, leading to low bioremediation efficiencies (Ron and Rosenberg, 2014). Researchers have found that using nitrogen-fixing hydrocarbon-degrading bacteria to improve the bioremediation efficiency was another good strategy instead of providing nitrogen sources (Thavasi et al., 2006). For aerobic degradation processes, using oxygen as an electron acceptor is quite important, but it is usually not adequate in petroleum oil-contaminated environments because of the limited air permeability. Gogoi et al. (2003) reported that up to $75 \%$ of the hydrocarbon contaminants were degraded within 1 year in field tests by controlling and regulating aeration. However, providing a sufficient oxygen supply to stimulate the bioremediation of petroleum pollutants in the environment is rather expensive and not feasible. Hence, the application of bulking agents such as saw dust into the soil to increase permeability or other electron acceptors $\left(\mathrm{NO}_{3}{ }^{-}, \mathrm{Fe}^{3+}\right.$, or $\left.\mathrm{Mn}^{2+}\right)$ into anoxic environments to stimulate anaerobic microorganisms is often more economical than oxygen supplementation (Zedelius et al., 2011; Brown et al., 2017).

\section{METABOLIC RESTRICTION}

The ability to biodegrade petroleum oil is associated with the concentration and composition of hydrocarbons. Extremely high levels of petroleum hydrocarbons strongly inhibit bacterial growth, resulting in poor biodegradation efficiency and even death of the bacteria (Ma et al., 2015). As reported by Varjani (2017), the order of biodegradability of hydrocarbons is as follows: linear alkanes $>$ branched alkanes $>$ low molecular weight alkyl aromatics $>$ monoaromatics $>$ cyclic alkanes $>$ polyaromatics $>$ asphaltenes. This is related to the physico-chemical properties of the substrate and its bioavailability, which affect the contact, transport and transformation of bacteria to hydrocarbon substrates (Varjani and Upasani, 2016). The vast majority of indoor studies are focused on the degradation of a single substrate, but in nature the components of petroleum hydrocarbon pollutants are extremely complex. Accordingly, it is difficult to reproduce laboratory results in practical applications. For example, Pseudomonas putida F1 can efficiently mineralize benzene, toluene and phenol. While in the substrate mixtures, toluene and benzene enhance the biodegradation of phenol; however, phenol inhibits the biodegradation of benzene and toluene (Abuhamed et al., 2004).

The key components of bacterial degradation of petroleum hydrocarbons are various specific enzymes (Wasmund et al., 2009; Varjani, 2017). For example, the enzymes alkane 


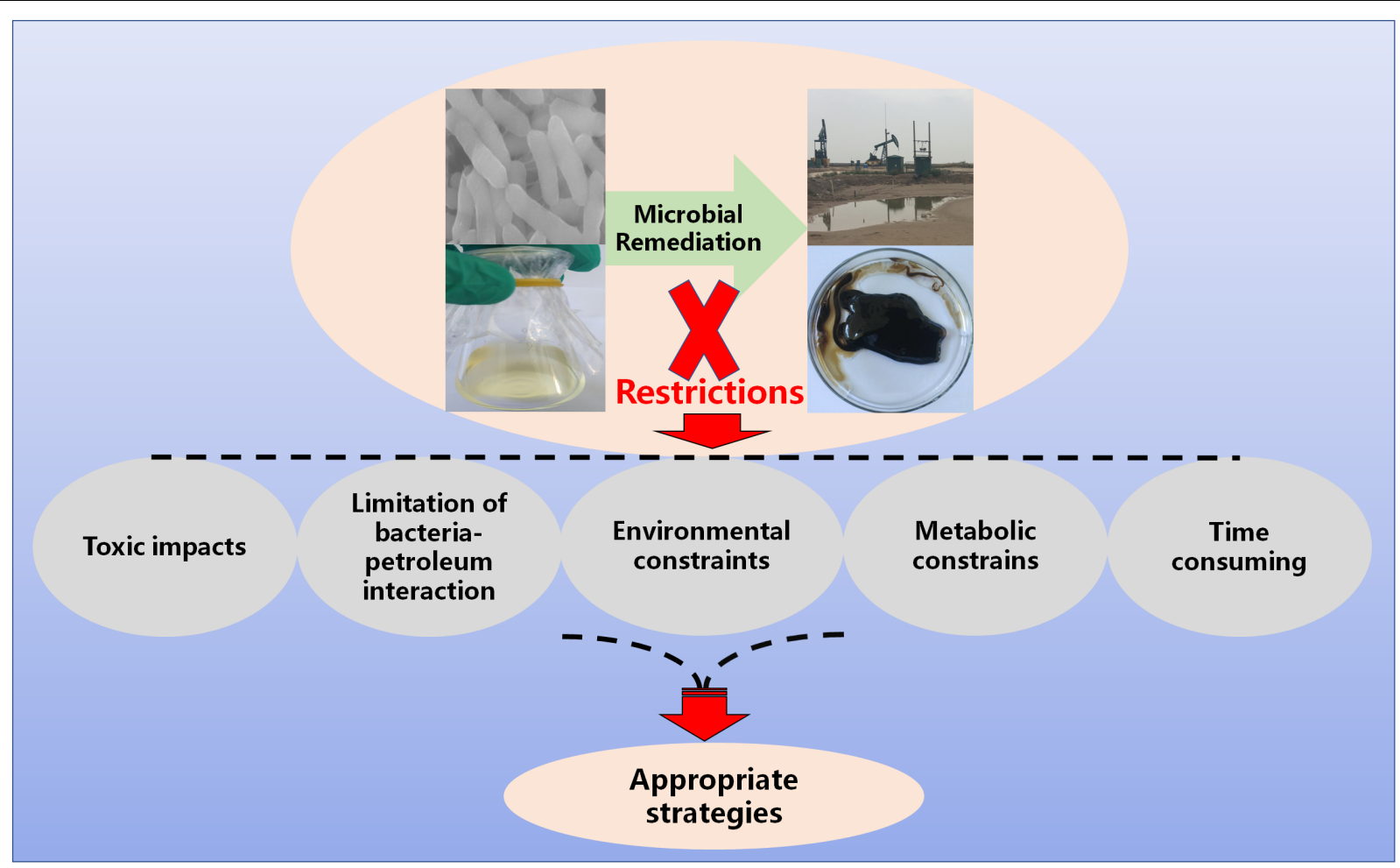

FIGURE 1 | Restrictions of microbial remediation.

1-monooxygenase, alcohol dehydrogenase, cyclohexanoldehydrogenase, methane monooxygenase and cyclohexanone 1,2 monooxygenase are involved in degradation of alkanes, while naphthalene 1,2-dioxygenase ferredoxin reductase component, cis-2,3-dihydrobiphenyl-2,3-diol dehydrogenase and salicylaldehyde dehydrogenase are associated with naphthalene degradation and benzene dioxygenase, toluene dioxygenase and ethylbenzene dioxygenase work on other petroleum hydrocarbons (Bacosa et al., 2018).

Many isolated bacteria possess the ability to mineralize chemically simple petroleum hydrocarbons completely, such as linear alkanes, as long as these bacteria possess all of the enzymes for the targeted substrate (Head et al., 2006; SethSmith, 2010; Margesin et al., 2013). However, few bacteria can completely mineralize complex compounds such as resins and asphaltenes because of the lack of some enzymes (Varjani, 2017). The advantages of microbial communities are presented because there are a variety of catabolic genes in a bacterial consortium, and the synergistic effects of these genes are beneficial to achieving the purification of pollutants (Gurav et al., 2017). A bacterial consortium composed of five culturable bacteria has been constructed by Wanapaisan et al. (2018). Researchers found that these five bacteria showed synergistic pyrene degradation due to the following aspects: (1) The Bacillus strain enhanced the bioavailability of the pyrene by producing biosurfactant, (2) two Mycobacterium strains contributed to the initiation of pyrene degradation, and (3) Novosphingobium and Ochrobactrum efficiently degraded the intermediates of pyrene. Given the complexity of the petroleum components, construction of the minimal functional bacterial consortium or genetic engineering bacteria for bioremediation of petroleum oil has become a trend in this field (Dvořák et al., 2017). However, the stability of the community and the safety of the engineered bacteria are additional problems that must be overcome.

\section{TIME CONSUMING}

The core element of bioremediation is functional microorganisms that need sufficient nutrients and suitable environmental conditions. In general, petroleum oil hydrocarbons are not necessary substrates for hydrocarbondegrading bacteria, and they utilize these compounds as alternative carbon and energy sources, especially in the absence of their preferable substrates. The function of hydrocarbon-degrading bacteria mainly depends on their hydrocarbon-degrading enzymes, the expression and activity of which are closely related to the physiological activity of bacteria (Mukherjee et al., 2017; Song et al., 2017). Sufficient time is needed to synthesize hydrocarbon-degrading enzymes because of the requirements of bacterial growth and synthetic metabolism. Although some bacteria have been reported to mineralize petroleum hydrocarbons completely within several days, or even less than 1 day under culture conditions, the degradation efficiency of these bacteria makes it difficult to meet the expected effects in practical usage (Chen et al., 2017; Zheng 


\section{Petroleum oil}

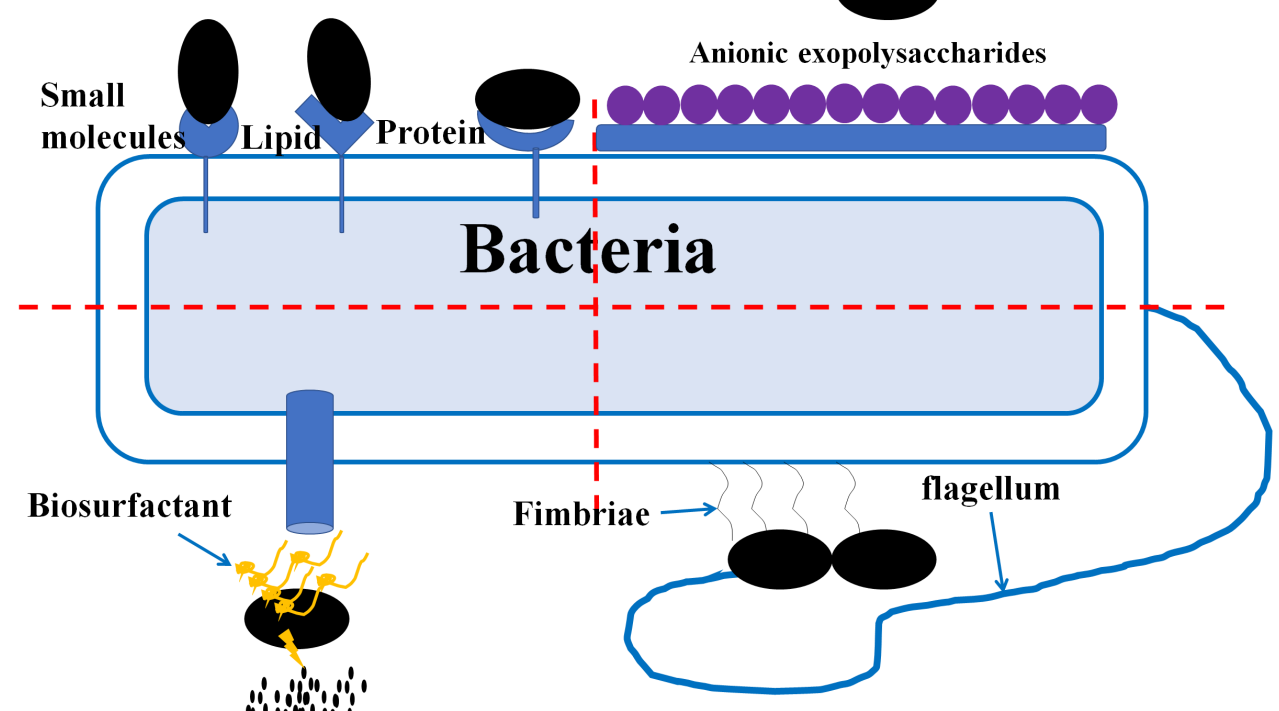

$>$ Fimbriae or flagellum of bacteria attach to petroleum oil.

$>$ Biosurfactants secreted by bacteria emulsify petroleum oil.

$>$ Proteins, lipids and other small molecules on bacterial surface for adhering petroleum oil.

$>$ Some anionic exopolysaccharides on bacterial surface prevent bacteria from attaching to petroleum oil.

et al., 2018). The complex combination of various biological and abiotic factors limits the function of petroleum hydrocarbondegrading bacteria in many ways (Zhao et al., 2017; Wang Y. et al., 2018). The degradation rate of petroleum hydrocarbon in the actual environment is the result of these factors acting on the petroleum hydrocarbon-degradation bacteria, which has led to most microbial remediation technologies taking a long time, especially when compared to physico-chemical remediation techniques. For instance, Fida et al. (2017) found that the green fluorescent protein (GFP) tagged variant of Novosphingobium sp. strain LH128 showed a dramatic decrease in colony forming units (CFU) within $4 \mathrm{~h}$ and entered a viable but nonculturable (VBNC)-like state upon inoculation into phenanthrene spiked soil based on physiological and transcriptome analysis, which could be related to the response to environmental stimuli in the soil by expression of stress protective mechanisms. This disadvantage makes it almost impossible to do anything when dealing with emergency pollution incidents because bioremediation will not remove contaminants as soon as the contamination occurs, but rather requires sufficient time to be achieved. In addition, there is no time to screen for indigenous bacteria or flora in contaminated accident zones, and the application of exogenous bacteria requires scientific assessment, government approval, etc., all of which will consume time (Ivshina et al., 2015). However, microbial remediation technology plays an irreplaceable role in ecological security when dealing with petroleum hydrocarbonpolluted environments due to its low cost, positive effect, little environmental influence and lack of secondary pollution (Dvořák et al., 2017). Moreover, petroleum hydrocarbons are completely mineralized into carbon dioxide and water under the action of various microbes, although bioremediation is time-consuming. Hence, to effectively reduce the microbial remediation period and improve the remediation rate, using a combination of microbial remediation technology and other technologies such as electrokinetic remediation technology $(\mathrm{Ma}$ et al., 2018), photocatalytic remediation technology (Xu et al., 2017), nanotechnology (Alabresm et al., 2018) and bioreactor technology (Safdari et al., 2018) is an effective strategy to accelerate the removal of petroleum hydrocarbon pollutants.

\section{CONCLUSION AND FUTURE OUTLOOK}

Petroleum hydrocarbons are one of the most alarming pollutants due to their high toxicity to human and environmental health. Bioremediation with petroleum hydrocarbon-degrading bacteria is widely regarded as an eco-friendly and efficient 
technology. A large amount of bacterial species with petroleum hydrocarbon-degrading ability have been exploited and applied in bioremediation. However, various problems that slow down biodegradation effects have been found during the process of practical application. This review highlighted these restriction factors, including the toxic effects of petroleum hydrocarbons, the bioavailability of pollutants, environmental constraints, metabolic restrictions and time consumption, and then summarized the current countermeasures against these problems. Several strategies, such as regulating environmental factors and optimizing microbial inoculants, have been investigated and fulfilled. Based on the current state of knowledge reviewed here, a series of investigations still needs to be conducted prior to the successful application of bioremediation for the restoration of petroleum oil contaminated environments. It is concluded as follows: (1) Continue the theoretical basis of the interfacial interaction mechanism between bacteria and petroleum hydrocarbons in order to overcome barriers for microbial uptake of petroleum hydrocarbons, (2) develop novel biocompatible surfactants to enhance contact between bacteria and petroleum hydrocarbons, (3) explore undiscovered resources of petroleum hydrocarbon-degrading bacteria via new biotechnology, such as a high-throughput screening method to increase and enrich functional bacterial resources, (4) further optimize the strategy of artificial microbial consortia, such as by way of the metagenome enrichment approach to enrich and develop preferable consortia, (5) explore the novel functional

\section{REFERENCES}

Abbasian, F., Lockington, R., Mallavarapu, M., and Naidu, R. (2015). A comprehensive review of aliphatic hydrocarbon biodegradation by bacteria. Appl. Biochem. Biotechnol. 176, 670-699. doi: 10.1007/s12010-015-1603-5

Abbasnezhad, H., Gray, M., and Foght, J. M. (2011). Influence of adhesion on aerobic biodegradation and bioremediation of liquid hydrocarbons. Appl. Microbiol. Biotechnol. 92, 653-675. doi: 10.1007/s00253-011-3589-4

Abed, R. M. M., Al-Kharusi, S., and Al-Hinai, M. (2015). Effect of biostimulation, temperature and salinity on respiration activities and bacterial community composition in an oil polluted desert soil. Int. Biodeterior. Biodegrad. 98, 43-52. doi: 10.1016/j.ibiod.2014.1 1.018

Abuhamed, T., Bayraktar, E., Mehmetoğlu, T., and Mehmetoğlu, Ü. (2004). Kinetics model for growth of Pseudomonas putida F1 during benzene, toluene and phenol biodegradation. Process Biochem. 39, 983-988. doi: 10.1016/S00329592(03)00210-3

Alabresm, A., Chen, Y. P., Decho, A. W., and Lead, J. (2018). A novel method for the synergistic remediation of oil-water mixtures using nanoparticles and oildegrading bacteria. Sci. Total Environ. 630, 1292-1297. doi: 10.1016/j.scitotenv. 2018.02.277

Ayed, H. B., Jemil, N., Maalej, H., Bayoudh, A., Hmidet, N., and Nasri, M. (2015). Enhancement of solubilization and biodegradation of diesel oil by biosurfactant from Bacillus amyloliquefaciens An6. Int. Biodeterior. Biodegrad. 99, 8-14. doi: 10.1016/j.ibiod.2014.1 2.009

Bacosa, H. P., Erdner, D. L., Rosenheim, B. E., Shetty, P., Seitz, K. W., Baker, B. J., et al. (2018). Hydrocarbon degradation and response of seafloor sediment bacterial community in the northern Gulf of Mexico to light Louisiana sweet crude oil. ISME J. 12, 2532-2543. doi: 10.1038/s41396-018-01901

Brown, D. M., Okoro, S., van Gils, J., van Spanning, R., Bonte, M., Hutchings, T., et al. (2017). Comparison of landfarming amendments to genes controlling the pathway of hydrocarbon degradation to provide new looks on the molecular mechanism and microbial remediation, and (6) construct genetically engineered bacteria by using synthetic biology technology to give them more ability for petroleum hydrocarbon degradation.

\section{AUTHOR CONTRIBUTIONS}

$\mathrm{XX}$ and HY contributed to the writing of the manuscript. WL, ST, WW, QQ, PJ, XG, FL, and HL contributed to the collection of literatures and summarization.

\section{FUNDING}

The authors gratefully acknowledge the National Key R\&D Program of China (2017YFC0505901), the National Natural Science Foundation of China (41877053), and the Project of Science and Technology Development Plan of Jilin Province (20160520025JH).

\section{ACKNOWLEDGMENTS}

We thank LetPub (www.letpub.com) for its linguistic assistance during the preparation of this manuscript.

improve bioremediation of petroleum hydrocarbons in Niger Delta soils. Sci. Total Environ. 596, 284-292. doi: 10.1016/j.scitotenv.2017.04.072

Brown, L. M., Gunasekera, T. S., Striebich, R. C., and Ruiz, O. N. (2016). Draft genome sequence of Gordonia sihwensis strain 9, a branched alkane-degrading bacterium. Genome Announc. 4:e00622-16. doi: 10.1128/genomeA.00622-16

Cerniglia, C. E., Freeman, J. P., Althaus, J. R., and van Baalen, C. (1983). Metabolism and toxicity of 1-and 2-methylnaphthalene and their derivatives in cyanobacteria. Arch. Microbiol. 136, 177-183. doi: 10.1007/BF00409840

Chaerun, S. K., Tazaki, K., Asada, R., and Kogure, K. (2004). Bioremediation of coastal areas 5 years after the Nakhodka oil spill in the Sea of Japan: isolation and characterization of hydrocarbon-degrading bacteria. Environ. Int. 30, 911-922. doi: 10.1016/j.envint.2004.02.007

Chen, M., Xu, P., Zeng, G., Yang, C., Huang, D., and Zhang, J. (2015). Bioremediation of soils contaminated with polycyclic aromatic hydrocarbons, petroleum, pesticides, chlorophenols and heavy metals by composting: applications, microbes and future research needs. Biotechnol. Adv. 33, 745-755. doi: 10.1016/j.biotechadv.2015.05.003

Chen, W., Li, J., Sun, X., Min, J., and Hu, X. (2017). High efficiency degradation of alkanes and crude oil by a salt-tolerant bacterium Dietzia species CN-3. Int. Biodeterior. Biodegrad. 118, 110-118. doi: 10.1016/j.ibiod.2017.01.029

Chen, Y. J., Wang, H. Q., Wang, R., and Yun, Y. (2007). Effects of rhamnolipid on the biodegradation of $n$-hexadecane by microorganism and the cell surface hydrophobicity. Environ. Sci. 28, 2117-2122.

Díez, S., Jover, E., Bayona, J. M., and Albaigés, J. (2007). Prestige oil spill. III. Fate of a heavy oil in the marine environment. Environ. Sci. Technol. 41, 3075-3082. doi: 10.1021/es0629559

Dombrowski, N., Donaho, J. A., Gutierrez, T., Seitz, K. W., Teske, A. P., and Baker, B. J. (2016). Reconstructing metabolic pathways of hydrocarbon-degrading bacteria from the Deepwater Horizon oil spill. Nat. Microbiol. 1:16057. doi: 10.1038/nmicrobiol.2016.57

Doyle, R. J. (2000). Contribution of the hydrophobic effect to microbial infection. Microbes Infect. 2, 391-400. doi: 10.1016/S1286-4579(00)00328-2 
Dvořák, P., Nikel, P. I., Damborský, J., and de Lorenzo, V. (2017). Bioremediation 3.0: engineering pollutant-removing bacteria in the times of systemic biology. Biotechnol. Adv. 35, 845-866. doi: 10.1016/j.biotechadv.2017.08.001

Eskandari, S., Hoodaji, M., Tahmourespour, A., Abdollahi, A., MohammadianBaghi, T., Eslamian, S., et al. (2017). Bioremediation of polycyclic aromatic hydrocarbons by Bacillus Licheniformis ATHE9 and Bacillus Mojavensis ATHE13 as newly strains isolated from oil-contaminated soil. J. Geogr. Environ. Earth Sci. Int. 11, 1-11. doi: 10.9734/JGEESI/2017/35447

Fida, T. T., Moreno-Forero, S. K., Breugelmans, P., Heipieper, H. J., Röling, W. F., and Springael, D. (2017). Physiological and transcriptome response of the polycyclic aromatic hydrocarbon degrading Novosphingobium sp. LH128 after inoculation in soil. Environ. Sci. Technol. 51, 1570-1579. doi: 10.1021/acs.est. $6 \mathrm{~b} 03822$

Fuentes, S., Barra, B., Caporaso, J. G., and Seeger, M. (2015). From rare to dominant: a fine-tuned soil bacterial bloom during petroleum hydrocarbon bioremediation. Appl. Environ. Microbiol. 82, 888-896. doi: 10.1128/AEM. 02625- 15

Ghosal, D., Ghosh, S., Dutta, T. K., and Ahn, Y. (2016). Current state of knowledge in microbial degradation of polycyclic aromatic hydrocarbons (PAHs): a review. Front. Microbiol. 7:1369. doi: 10.3389/fmicb.2016.01369

Gogoi, B. K., Dutta, N. N., Goswami, P., and Mohan, T. K. (2003). A case study of bioremediation of petroleum-hydrocarbon contaminated soil at a crude oil spill site. Adv. Environ. Res. 7, 767-782. doi: 10.1016/S1093-0191(02)00029-1

Guerra, A. B., Oliveira, J. S., Silva-Portela, R. C., Araujo, W., Carlos, A. C., Vasconcelos, A. T. R., et al. (2018). Metagenome enrichment approach used for selection of oil-degrading bacteria consortia for drill cutting residue bioremediation. Environ. Pollut. 235, 869-880. doi: 10.1016/j.envpol.2018.01. 014

Gurav, R., Lyu, H., Ma, J., Tang, J., Liu, Q., and Zhang, H. (2017). Degradation of n-alkanes and PAHs from the heavy crude oil using salt-tolerant bacterial consortia and analysis of their catabolic genes. Environ. Sci. Pollut. Res. 24, 11392-11403. doi: 10.1007/s11356-017-8446-2

Hara, A., Syutsubo, K., and Harayama, S. (2003). Alcanivorax which prevails in oil-contaminated seawater exhibits broad substrate specificity for alkane degradation. Environ. Microbiol. 5, 746-753. doi: 10.1046/j.1468-2920.2003. 00468.x

Hazen, T. C., Dubinsky, E. A., DeSantis, T. Z., Andersen, G. L., Piceno, Y. M., Singh, N., et al. (2010). Deep-sea oil plume enriches indigenous oil-degrading bacteria. Science 330, 204-208. doi: 10.1126/science.1195979

Hazen, T. C., Prince, R. C., and Mahmoudi, N. (2016). Marine oil biodegradation. Environ. Sci. Technol. 50, 2121-2129. doi: 10.1021/acs.est.5b03333

Head, I. M., Jones, D. M., and Röling, W. F. (2006). Marine microorganisms make a meal of oil. Nat. Rev. Microbiol. 4:173. doi: 10.1038/nrmicro 1348

Hedlund, B. P., Geiselbrecht, A. D., Bair, T. J., and Staley, J. T. (1999). Polycyclic aromatic hydrocarbon degradation by a new marine bacterium, Neptunomonas naphthovorans gen. nov., sp. nov. Appl. Environ. Microbiol. 65, 251-259.

Heipieper, H. J., Neumann, G., Cornelissen, S., and Meinhardt, F. (2007). Solventtolerant bacteria for biotransformations in two-phase fermentation systems. Appl. Microbiol. Biotechnol. 74, 961-973. doi: 10.1007/s00253-006-0833-4

Hou, N., Zhang, N., Jia, T., Sun, Y., Dai, Y., Wang, Q., et al. (2018). Biodegradation of phenanthrene by biodemulsifier-producing strain Achromobacter sp. LH-1 and the study on its metabolisms and fermentation kinetics. Ecotoxicol. Environ. Saf. 163, 205-214. doi: 10.1016/j.ecoenv.2018.07.064

Hua, F., and Wang, H. Q. (2014). Uptake and trans-membrane transport of petroleum hydrocarbons by microorganisms. Biotechnol. Biotechnol. Equip. 28, 165-175. doi: 10.1080/13102818.2014.906136

Inakollu, S., Hung, H. C., and Shreve, G. S. (2004). Biosurfactant enhancement of microbial degradation of various structural classes of hydrocarbon in mixed waste systems. Environ. Eng. Sci. 21, 463-469. doi: 10.1089/1092875041358467

Ivshina, I. B., Kuyukina, M. S., Krivoruchko, A. V., Elkin, A. A., Makarov, S. O., Cunningham, C. J., et al. (2015). Oil spill problems and sustainable response strategies through new technologies. Environ. Sci. 17, 1201-1219. doi: 10.1039/ c5em00070j

Jahromi, H., Fazaelipoor, M. H., Ayatollahi, S., and Niazi, A. (2014). Asphaltenes biodegradation under shaking and static conditions. Fuel 117, 230-235. doi: 10.1016/j.fuel.2013.09.085
Jiang, C. Y., Dong, L., Zhao, J. K., Hu, X., Shen, C., Qiao, Y., et al. (2016). High throughput single-cell cultivation on microfluidic streak plates. Appl. Environ. Microbiol. 82, 2210-2218. doi: 10.1128/AEM.03588-15

Jin, H. M., Kim, J. M., Lee, H. J., Madsen, E. L., and Jeon, C. O. (2012). Alteromonas as a key agent of polycyclic aromatic hydrocarbon biodegradation in crude oil-contaminated coastal sediment. Environ. Sci. Technol. 46, 7731-7740. doi: $10.1021 /$ es 3018545

Kaczorek, E., Jesionowski, T., Giec, A., and Olszanowski, A. (2012). Cell surface properties of Pseudomonas stutzeri in the process of diesel oil biodegradation. Biotechnol. Lett. 34, 857-862. doi: 10.1007/s10529-011-0835-x

Kasai, Y., Kishira, H., and Harayama, S. (2002). Bacteria belonging to the genus Cycloclasticus play a primary role in the degradation of aromatic hydrocarbons released in a marine environment. Appl. Environ. Microbiol. 68, 5625-5633. doi: 10.1128/AEM.68.11.5625-5633.2002

Kleindienst, S., Paul, J. H., and Joye, S. B. (2015a). Using dispersants after oil spills: impacts on the composition and activity of microbial communities. Nat. Rev. Microbiol. 13, 388-396. doi: 10.1038/nrmicro3452

Kleindienst, S., Seidel, M., Ziervogel, K., Grim, S., Loftis, K., Harrison, S., et al. (2015b). Chemical dispersants can suppress the activity of natural oil-degrading microorganisms. Proc. Natl. Acad. Sci. U.S.A. 112, 14900-14905. doi: 10.1073/ pnas. 1507380112

Krasowska, A., and Sigler, K. (2014). How microorganisms use hydrophobicity and what does this mean for human needs? Front. Cell. Infect. Microbiol. 4:112. doi: $10.3389 /$ fcimb.2014.00112

Labud, V., Garcia, C., and Hernandez, T. (2007). Effect of hydrocarbon pollution on the microbial properties of a sandy and a clay soil. Chemosphere 66, 1863-1871. doi: 10.1016/j.chemosphere.2006.08.021

Laha, S., and Luthy, R. G. (1991). Inhibition of phenanthrene mineralization by nonionic surfactants in soil-water systems. Environ. Sci. Technol. 25, 19201930. doi: $10.1021 / \mathrm{es} 00023 \mathrm{a} 013$

Lea-Smith, D. J., Biller, S. J., Davey, M. P., Cotton, C. A., Sepulveda, B. M. P., Turchyn, A. V., et al. (2015). Contribution of cyanobacterial alkane production to the ocean hydrocarbon cycle. Proc. Natl. Acad. Sci. U.S.A. 112, 13591-13596. doi: 10.1073/pnas.1507274112

Lee, E. H., and Cho, K. S. (2008). Characterization of cyclohexane and hexane degradation by Rhodococcus sp. EC1. Chemosphere 71, 1738-1744. doi: 10. 1016/j.chemosphere.2007.12.009

Li, D., Xu, X., Zhai, Z., Yu, H., and Han, X. (2017). Isolation and identification an $\mathrm{n}$-hexadecane bacterial degrader from soil polluted by petroleum oil in Momoge wetlands and its degradation characteristics. Wetland Sci. 15, 85-91.

Liu, S., Guo, C., Liang, X., Wu, F., and Dang, Z. (2016). Nonionic surfactants induced changes in cell characteristics and phenanthrene degradation ability of Sphingomonas sp. GY2B. Ecotoxicol. Environ. Saf. 129, 210-218. doi: 10.1016/j. ecoenv.2016.03.035

Ma, Y., Li, X., Mao, H., Wang, B., and Wang, P. (2018). Remediation of hydrocarbon-heavy metal co-contaminated soil by electrokinetics combined with biostimulation. Chem. Eng. J. 353, 410-418. doi: 10.1016/j.cej.2018.07.131

Ma, Y. L., Lu, W., Wan, L. L., and Luo, N. (2015). Elucidation of fluoranthene degradative characteristics in a newly isolated Achromobacter xylosoxidans DN002. Appl. Biochem. Biotechnol. 175, 1294-1305. doi: 10.1007/s12010-0141347-7

Margesin, R., Labbé, D., Schinner, F., Greer, C. W., and Whyte, L. G. (2003). Characterization of hydrocarbon-degrading microbial populations in contaminated and pristine alpine soils. Appl. Environ. Microbiol. 69, 3085-3092. doi: 10.1128/AEM.69.6.3085-3092.2003

Margesin, R., Moertelmaier, C., and Mair, J. (2013). Low-temperature biodegradation of petroleum hydrocarbons (n-alkanes, phenol, anthracene, pyrene) by four actinobacterial strains. Int. Biodeterior. Biodegrad. 84, 185-191. doi: $10.1016 /$ j.ibiod.2012.05.004

Mason, O. U., Hazen, T. C., Borglin, S., Chain, P. S. G., Dubinsky, E. A., Fortney, J. L., et al. (2012). Metagenome, metatranscriptome and single-cell sequencing reveal microbial response to Deepwater Horizon oil spill. ISME J. 6, 1715-1727. doi: 10.1038 /ismej.2012.59

Megharaj, M., Ramakrishnan, B., Venkateswarlu, K., Sethunathan, N., and Naidu, R. (2011). Bioremediation approaches for organic pollutants: a critical perspective. Environ. Int. 37, 1362-1375. doi: 10.1016/j.envint.2011.06.003

Mnif, S., Sayadi, S., and Chamkha, M. (2014). Biodegradative potential and characterization of a novel aromatic-degrading bacterium isolated from a 
geothermal oil field under saline and thermophilic conditions. Int. Biodeterior Biodegrad. 86, 258-264. doi: 10.1016/j.ibiod.2013.09.015

Mukherjee, A. K., Bhagowati, P., Biswa, B. B., Chanda, A., and Kalita, B. (2017). A comparative intracellular proteomic profiling of Pseudomonas aeruginosa strain ASP-53 grown on pyrene or glucose as sole source of carbon and identification of some key enzymes of pyrene biodegradation pathway. J. Proteomics 167, 25-35. doi: 10.1016/j.jprot.2017.07.020

Mukherjee, S., Bardolui, N. K., Karim, S., Patnaik, V. V., Nandy, R. K., and Bag, P. K. (2010). Isolation and characterization of a monoaromatic hydrocarbondegrading bacterium, Pseudomonas aeruginosa from crude oil. J. Environ. Sci. Health Part A 45, 1048-1053. doi: 10.1080/10934529.2010.486328

Nie, Y., Liang, J. L., Fang, H., Tang, Y. Q., and Wu, X. L. (2014). Characterization of a CYP153 alkane hydroxylase gene in a gram-positive Dietzia sp. DQ1245-1b and its "team role" with alkw1 in alkane degradation. Appl. Microbiol. Biotechnol. 98, 163-173. doi: 10.1007/s00253-013-4821-1

Obuekwe, C. O., Al-Jadi, Z. K., and Al-Saleh, E. S. (2009). Hydrocarbon degradation in relation to cell-surface hydrophobicity among bacterial hydrocarbon degraders from petroleum-contaminated Kuwait desert environment. Int. Biodeterior. Biodegrad. 63, 273-279. doi: 10.1016/j.ibiod. 2008.10.004

Overholt, W. A., Marks, K. P., Romero, I. C., Hollander, D. J., Snell, T. W., and Kostka, J. E. (2015). Hydrocarbon degrading bacteria exhibit a species specific response to dispersed oil while moderating ecotoxicity. Appl. Environ. Microbiol. 82, 518-527. doi: 10.1128/AEM.02379-15

Rivers, A. R., Sharma, S., Tringe, S. G., Martin, J., Joye, S. B., and Moran, M. A. (2013). Transcriptional response of bathypelagic marine bacterioplankton to the Deepwater Horizon oil spill. ISME J. 7:2315. doi: 10.1038/ismej.2013.129

Röling, W. F., Milner, M. G., Jones, D. M., Fratepietro, F., Swannell, R. P., Daniel, F., et al. (2004). Bacterial community dynamics and hydrocarbon degradation during a field-scale evaluation of bioremediation on a mudflat beach contaminated with buried oil. Appl. Environ. Microbiol. 70, 2603-2613. doi: 10.1128/AEM.70.5.2603-2613.2004

Röling, W. F., Milner, M. G., Jones, D. M., Lee, K., Daniel, F., Swannell, R. J., et al. (2002). Robust hydrocarbon degradation and dynamics of bacterial communities during nutrient-enhanced oil spill bioremediation. Appl. Environ. Microbiol. 68, 5537-5548. doi: 10.1128/AEM.68.11.5537-5548.2002

Ron, E. Z., and Rosenberg, E. (2014). Enhanced bioremediation of oil spills in the sea. Curr. Opin. Biotechnol. 27, 191-194. doi: 10.1016/j.copbio.2014.02.004

Rosenberg, M., and Rosenberg, E. (1985). Bacterial adherence at the hydrocarbonwater interface. Oil Petrochem. Pollut. 2, 155-162. doi: 10.1016/S0143-7127(85) 90178-4

Safdari, M. S., Kariminia, H. R., Rahmati, M., Fazlollahi, F., Polasko, A., Mahendra, S., et al. (2018). Development of bioreactors for comparative study of natural attenuation, biostimulation, and bioaugmentation of petroleumhydrocarbon contaminated soil. J. Hazard. Mater. 342, 270-278. doi: 10.1016/j. jhazmat.2017.08.044

Sarkar, P., Roy, A., Pal, S., Mohapatra, B., Kazy, S. K., Maiti, M. K., et al. (2017). Enrichment and characterization of hydrocarbon-degrading bacteria from petroleum refinery waste as potent bioaugmentation agent for in situ bioremediation. Bioresour. Technol. 242, 15-27. doi: 10.1016/j.biortech.2017.05. 010

Seth-Smith, H. (2010). 'Slick'operation. Nature 8:538.

Sikkema, J., de Bont, J. A., and Poolman, B. (1995). Mechanisms of membrane toxicity of hydrocarbons. Microbiol. Rev. 59, 201-222.

Song, M., Yang, Y., Jiang, L., Hong, Q., Zhang, D., Shen, Z., et al. (2017). Characterization of the phenanthrene degradation-related genes and degrading ability of a newly isolated copper-tolerant bacterium. Environ. Pollut. 220, 1059-1067. doi: 10.1016/j.envpol.2016.11.037

Sugiura, K., Ishihara, M., Shimauchi, T., and Harayama, S. (1997). Physiochemical properties and biodegradability of crude oil. Environ. Sci. Technol. 31, 45-51. doi: $10.1021 /$ es $950961 \mathrm{r}$

Sun, Y. (2009). On-site management of international petroleum cooperation projects. Nat. Gas Explor. Dev.

Szulc, A., Ambrożewicz, D., Sydow, M., Ławniczak, Ł., Piotrowska-Cyplik, A., Marecik, R., et al. (2014). The influence of bioaugmentation and biosurfactant addition on bioremediation efficiency of diesel-oil contaminated soil: feasibility during field studies. J. Environ. Manage. 132, 121-128. doi: 10.1016/j.jenvman. 2013.11.006
Tao, K., Liu, X., Chen, X., Hu, X., Cao, L., and Yuan, X. (2017). Biodegradation of crude oil by a defined co-culture of indigenous bacterial consortium and exogenous Bacillus subtilis. Bioresour. Technol. 224, 327-332. doi: 10.1016/j. biortech.2016.10.073

Tavassoli, T., Mousavi, S. M., Shojaosadati, S. A., and Salehizadeh, H. (2012). Asphaltene biodegradation using microorganisms isolated from oil samples. Fuel 93, 142-148. doi: 10.1016/j.fuel.2011.10.021

Thavasi, R., Jayalakshmi, S., Baalasubramanian, T., and Banat, I. M. (2006). Biodegradation of crude oil by nitrogen fixing marine bacteria Azotobacter chroococcum. Res. J. Microbiol. 1, 401-408. doi: 10.3923/jm.2006.401.408

Torres, S., Pandey, A., and Castro, G. R. (2011). Organic solvent adaptation of Gram positive bacteria: applications and biotechnological potentials. Biotechnol. Adv. 29, 442-452. doi: 10.1016/j.biotechadv.2011.04.002

Tremblay, J., Yergeau, E., Fortin, N., Cobanli, S., Elias, M., King, T. L., et al. (2017). Chemical dispersants enhance the activity of oil-and gas condensate-degrading marine bacteria. ISME J. 11, 2793-2808. doi: 10.1038/ismej.2017.129

van Dorst, J., Siciliano, S. D., Winsley, T., Snape, I., and Ferrari, B. C. (2014). Bacterial targets as potential indicators of diesel fuel toxicity in subantarctic soils. Appl. Environ. Microbiol. 80, 4021-4033. doi: 10.1128/AEM.03939-13

Varjani, S. J. (2017). Microbial degradation of petroleum hydrocarbons. Bioresour. Technol. 223, 277-286. doi: 10.1016/j.biortech.2016.10.037

Varjani, S. J., and Gnansounou, E. (2017). Microbial dynamics in petroleum oilfields and their relationship with physiological properties of petroleum oil reservoirs. Bioresour. Technol. 245, 1258-1265. doi: 10.1016/j.biortech.2017.08.028

Varjani, S. J., Rana, D. P., Jain, A. K., Bateja, S., and Upasani, V. N. (2015). Synergistic ex-situ biodegradation of crude oil by halotolerant bacterial consortium of indigenous strains isolated from on shore sites of Gujarat. India. Int. Biodeterior. Biodegrad. 103, 116-124. doi: 10.1016/j.ibiod.2015.03.030

Varjani, S. J., and Upasani, V. N. (2016). Biodegradation of petroleum hydrocarbons by oleophilic strain of Pseudomonas aeruginosa NCIM 5514. Bioresour. Technol. 222, 195-201. doi: 10.1016/j.biortech.2016.10.006

Varjani, S. J., and Upasani, V. N. (2017). A new look on factors affecting microbial degradation of petroleum hydrocarbon pollutants. Int. Biodeterior. Biodegrad. 120, 71-83. doi: 10.1016/j.ibiod.2017.02.006

Vasileva-Tonkova, E., Galabova, D., Stoimenova, E., and Lalchev, Z. (2008). Characterization of bacterial isolates from industrial wastewater according to probable modes of hexadecane uptake. Microbiol. Res. 163, 481-486. doi: 10. 1016/j.micres.2006.07.015

Venkateswaran, K., Hoaki, T., Kato, M., and Maruyama, T. (1995). Microbial degradation of resins fractionated from Arabian light crude oil. Can. J. Microbiol. 41, 418-424. doi: 10.1139/m95-055

Wanapaisan, P., Laothamteep, N., Vejarano, F., Chakraborty, J., Shintani, M., Muangchinda, C., et al. (2018). Synergistic degradation of pyrene by five culturable bacteria in a mangrove sediment-derived bacterial consortium. J. Hazard. Mater. 342, 561-570. doi: 10.1016/j.jhazmat.2017.08.062

Wang, C., Liu, X., Guo, J., Lv, Y., and Li, Y. (2018). Biodegradation of marine oil spill residues using aboriginal bacterial consortium based on Penglai 19-3 oil spill accident. China. Ecotoxicol. Environ. Saf. 159, 20-27. doi: 10.1016/j.ecoenv. 2018.04.059

Wang, Y., Liang, J., Wang, J., and Gao, S. (2018). Combining stable carbon isotope analysis and petroleum-fingerprinting to evaluate petroleum contamination in the Yanchang oilfield located on loess plateau in China. Environ. Sci. Pollut. Res. 25, 2830-2841. doi: 10.1007/s11356-017-0500-6

Wang, X. B., Chi, C. Q., Nie, Y., Tang, Y. Q., Tan, Y., Wu, G., et al. (2011). Degradation of petroleum hydrocarbons (C6-C40) and crude oil by a novel Dietzia strain. Bioresour. Technol. 102, 7755-7761. doi: 10.1016/j.biortech.2011. 06.009

Wasmund, K., Burns, K. A., Kurtböke, D. I., and Bourne, D. G. (2009). Novel alkane hydroxylase gene (alkB) diversity in sediments associated with hydrocarbon seeps in the Timor Sea. Australia. Appl. Environ. Microbiol. 75, 7391-7398. doi: 10.1128/AEM.01370-09

Xu, X., Zhai, Z., Li, H., Wang, Q., Han, X., and Yu, H. (2017). Synergetic effect of bio-photocatalytic hybrid system: g-C3N4, and Acinetobacter, sp. JLS1 for enhanced degradation of C16 alkane. Chem. Eng. J. 323, 520-529. doi: 10.1016/ j.cej.2017.04.138

Xue, J., Yu, Y., Bai, Y., Wang, L., and Wu, Y. (2015). Marine oil-degrading microorganisms and biodegradation process of petroleum hydrocarbon in 
marine environments: a review. Curr. Microbiol. 71, 220-228. doi: 10.1007/ s00284-015-0825-7

Yakimov, M. M., Giuliano, L., Gentile, G., Crisafi, E., Chernikova, T. N., Abraham, W. R., et al. (2003). Oleispira antarctica gen. nov., sp. nov., a novel hydrocarbonoclastic marine bacterium isolated from Antarctic coastal sea water. Int. J. Syst. Evol. Microbiol. 53, 779-785. doi: 10.1099/ijs.0.02366-0

Yakimov, M. M., Timmis, K. N., and Golyshin, P. N. (2007). Obligate oil-degrading marine bacteria. Curr. Opin. Biotechnol. 18, 257-266. doi: 10.1016/j.copbio. 2007.04.006

Yang, Y., Wang, J., Liao, J., Xie, S., and Huang, Y. (2015). Abundance and diversity of soil petroleum hydrocarbon-degrading microbial communities in oil exploring areas. Appl. Microbiol. Biotechnol. 99, 1935-1946. doi: 10.1007/ s00253-014-6074-z

Zedelius, J., Rabus, R., Grundmann, O., Werner, I., Brodkorb, D., Schreiber, F., et al. (2011). Alkane degradation under anoxic conditions by a nitrate-reducing bacterium with possible involvement of the electron acceptor in substrate activation. Environ. Microbiol. Rep. 3, 125-135. doi: 10.1111/j.1758-2229.2010.0 0198.x

Zhang, L., Zhang, C., Cheng, Z., Yao, Y., and Chen, J. (2013). Biodegradation of benzene, toluene, ethylbenzene, and o-xylene by the bacterium Mycobacterium cosmeticum byf-4. Chemosphere 90, 1340-1347. doi: 10.1016/j.chemosphere. 2012.06.043

Zhang, X., Zhang, Q., Yan, T., Jiang, Z., Zhang, X., and Zuo, Y. Y. (2015). Quantitatively predicting bacterial adhesion using surface free energy determined with a spectrophotometric method. Environ. Sci. Technol. 49, 6164-6171. doi: 10.1021/es5050425
Zhao, D., Kumar, S., Zhou, J., Wang, R., Li, M., and Xiang, H. (2017). Isolation and complete genome sequence of Halorientalis hydrocarbonoclasticus sp. nov., a hydrocarbon-degrading haloarchaeon. Extremophiles 21, 1081-1090. doi: 10. 1007/s00792-017-0968-5

Zheng, J., Feng, J. Q., Zhou, L., Mbadinga, S. M., Gu, J. D., and Mu, B. Z. (2018). Characterization of bacterial composition and diversity in a long-term petroleum contaminated soil and isolation of high-efficiency alkane-degrading strains using an improved medium. World J. Microbiol. Biotechnol. 34:34. doi: 10.1007/s11274-018-2417-8

Zhukov, D. V., Murygina, V. P., and Kalyuzhnyi, S. V. (2007). Kinetics of the degradation of aliphatic hydrocarbons by the bacteria Rhodococcus ruber and Rhodococcus erythropolis. Appl. Biochem. Microbiol. 43, 587-592. doi: 10.1134/S00036838070 60038

Conflict of Interest Statement: The authors declare that the research was conducted in the absence of any commercial or financial relationships that could be construed as a potential conflict of interest.

Copyright (C) $2018 \mathrm{Xu}$, Liu, Tian, Wang, Qi, Jiang, Gao, Li, Li and Yu. This is an open-access article distributed under the terms of the Creative Commons Attribution License (CC BY). The use, distribution or reproduction in other forums is permitted, provided the original author(s) and the copyright owner(s) are credited and that the original publication in this journal is cited, in accordance with accepted academic practice. No use, distribution or reproduction is permitted which does not comply with these terms. 